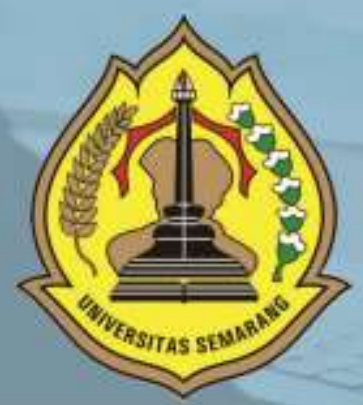

PENGARUH WORK FAMILY CONFLICT, STRES KERJA DAN KEPEMIMPINAN TERHADAP TURNOVER INTENTION KARYAWAN (STUDI PADA SELURUH KARYAWAN BAGIAN PLANNING PRODUCTION AND INVENTORY CONTROL PT. PARKLAND WORLD INDONESIA JEPARA

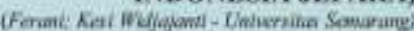

STUDI SOFT SKILL LULUSAN PENDIDIKAN KEJURUAN DI TEMPAT KERJA

Whort-Chiversikio Semorang

ANALISIS IINGKUNGAN INTERNAL DAN EKSTERNAL, PADA UKM PREMIUM PLUS LAUNDRY CABANG MULAWARMAN SEMARANG

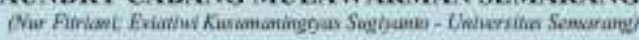

FAKTOR-FAKTOR YANG MEMPENGARUHI PERTIMBANGAN TINGKAT MATERIALITAS AUDIT

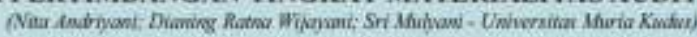

MANAJEMEN LABA DAN FAKTOR-FAKTOR YANG MEMPENGARUHINYA (STUDI EMPIRIS PADA PERUSAHAN MANUFAKTUR DI BEI)

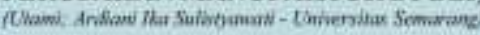

PENDAPATAN ASLI DAERAH, DANA PERIMBANGAN, DAN SISA LEBIH PEMBIAYAAN ANGGARAN TERHADAP PENGALOKASIAN BELANJA MODAL: STUDI PADA KABUPATEN/KOTA DI PROVINSI JAWA TENGAH

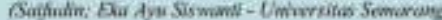

PERSEPSI PENGGUNA JASA TRANS JATENG TERHADAP KUALITAS PELAYANAN ANGKUTAN AGLOMERASI PERKOTAAN TRANS

JATENG

(Studi Kasus Trans Jateng Koridor I Semarang (Tawang) - Bawen)

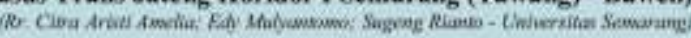

WORTHLESSNESS IS A POWER: MENGAPA ORANG BERSEDIA MENARUH UANG DI APLIKASI GO-PAY

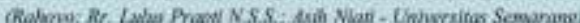

ANALISIS PENGARUH KUALITAS PRODUK, PERSEPSI HARGA, DAN PROMOSI TERHADAP KEPUTUSAN PEMBEIIAN WELLBLUE AL KALINE WATER PITCHER

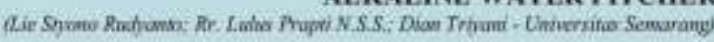

STRATEGI PEMASARAN UNTUK MENINGKATKAN VOLUME PENJUALAN (STUDI KASUS PADA SHOFA CATERING)

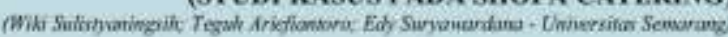

PENGARUH CITRA MEREK, PERSEPSI HARGA, DAN KUALITAS PRODUK TERHADAP KEPUTUSAN PEMBELIAN SEPATU OLAH RAGA MEREK ADIDAS

(Studi di Kota Semarang)

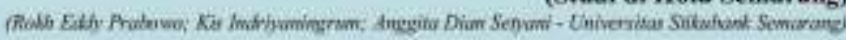

PENGARUH KEMUDAHAN TERHADAP KEPUTUSAN MENGGUNAKAN E-BANKING PADA BNI 46 KC KARANGAYU SEMARANG DENGAN MINAT NASABAH DAN KEPERCAYAAN SEBAGAI VARIABEL. MEDIASI

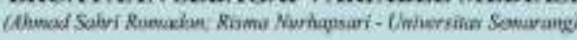

PENELITLAN KEBERLANGSUNGAN USAHA ARDANI INDONESIA SEBAGAI UMKM BERBASIS INDUSTRI KREATIF

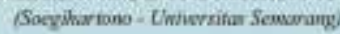

STRATEGI PELAYANAN BUS RAPID TRANSIT (BRT) TRANS SEMARANG

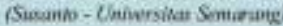

ANALISIS PENGARUH KEPEMIMPINAN, STRES KERJA, DAN LINGKUNGAN KERJA TERHADAP KINERJA KARYAWAN BAGIAN PRODUKSI SEWING PT. SAMWON BUSANA INDONESIA SEMARANG

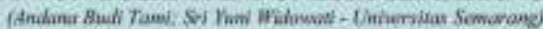




\section{DESKRIPSI}

Majalah IImiah Solusi Mengkaji

Masalah-Masalah Sosial,

Ekonomi dan Bisnis

\section{KETERANGAN TERBIT}

Terbit Pertama Kali Juli 2002

dan SelanjutnyaTerbit Tiga Bulan

Sekali (Januari, April, Juli dan

Oktober)

\section{PENERBIT}

Fakultas Ekonomi USM

\section{ALAMAT PENERBIT}

JL. Soekarno Hatta Semarang

Telp. 024-6702757 Fax. 024-6702272

\section{PENGELOLA}

Editor in Chief : Yohanes Suhardjo, SE, M.Si., Ak, CA Vice Editor Chief : Sugeng Rianto, SE, MM

Managing Editor: Edy Suryawardana, SE, MM

Secretary of Managing Editor : Asih Niati, SE, MM

Administration \& Circulation :

Citra Rizkiana, SE, MM

Layout \& Typesetting : M Burhan Hanif S.Kom, M.Kom

Board of Editors:

1. Prof. Dr. Ir. Kesi Widjajanti, SE, MM (USM)

2. Prof. Drs. Mohammad Nasir, Msi, Ph.D, AK. (USM)

3. Prof. Supramono SE, MBA, DBA (UKSW)

4. Prof. Drs. H. Imam Ghozali, M.Com, Akt, PhD (UNDIP)

5. Prof. Dr. Agus Suroso, MS (UNSOED)

6. Prof. Dr. Widodo, SE, M.Si (UNISSULA)

7. Prof. Dr. Dra. Sulastri, ME, M.Kom (UNSRI)

8. Dr. Ardiani Ika S, SE, MM, Ak, CA, CPA (USM)

\section{KATA PENGANTAR}

Sungguh merupakan kebahagiaan tersendiri bagi kami, takala kami dapat hadir rutin setiap tiga bulan sekali untuk saling bertukar pikiran mengenai hal-hal baru dibidang sosial, ekonomi dan bisnis.

Pada kesempatan ini penerbit menyampaikan terima kasih kepada semua pihak yang telah mengirimkan artikel-artikelnya. Penerbit akan membuka kesempatan seluas-luasnya bagi seluruh kalangan akademisi maupun praktisi baik dari dalam maupun luar Universitas Semarang untuk mempublikasikan karya ilmiahnya.

Penerbitan majalah ilmiah "SOLUSI" kali ini menghadirkan 15 (Lima Belas) artikel yang kami anggap layak untuk diterbitkan, dengan harapan dapat menjadi tambahan referensi bagi para pembaca dan menjadi sumbangan pengembangan persemaian khasanah pengetahuan dibidang sosial, ekonomi dan bisnis.

Akhir kata semoga majalah ilmiah "SOLUSI" dapat memberi manfaat yang sebesar-besarnya.

Hormat Kami 


\section{DAFTAR ISI}

PENGARUH WORK FAMILY CONFLICT, STRES KERJA DAN KEPEMIMPINAN TERHADAP TURNOVER INTENTION KARYAWAN (STUDI PADA SELURUH KARYAWAN BAGIAN PLANNING PRODUCTION AND INVENTORY CONTROL PT. PARKLAND WORLD INDONESIA JEPARA)

(Ferani; Kesi Widjajanti - Universitas Semarang)

STUDI SOFT SKILL LULUSAN PENDIDIKAN KEJURUAN DI TEMPAT KERJA

(Albert - Universitas Semarang)...

ANALISIS LINGKUNGAN INTERNAL DAN EKSTERNAL PADA UKM PREMIUM PLUS

LAUNDRY CABANG MULAWARMAN SEMARANG

(Nur Fitriani; Eviatiwi Kusumaningtyas Sugiyanto - Universitas Semarang)

FAKTOR-FAKTOR YANG MEMPENGARUHI PERTIMBANGAN TINGKAT

MATERIALITAS AUDIT

(Nita Andriyani; Dianing Ratna Wijayani; Sri Mulyani - Universitas Muria Kudus).

MANAJEMEN LABA DAN FAKTOR-FAKTOR YANG MEMPENGARUHINYA

(STUDI EMPIRIS PADA PERUSAHAN MANUFAKTUR DI BEI)

(Utami; Ardiani Ika Sulistyawati - Universitas Semarang)

PENDAPATAN ASLI DAERAH, DANA PERIMBANGAN, DAN SISA LEBIH PEMBIAYAAN ANGGARAN TERHADAP PENGALOKASIAN BELANJA MODAL: STUDI PADA

KABUPATEN/KOTA DI PROVINSI JAWA TENGAH

(Saifudin; Eka Ayu Siswanti - Universitas Semarang).

PERSEPSI PENGGUNA JASA TRANS JATENG TERHADAP KUALITAS PELAYANAN ANGKUTAN AGLOMERASI PERKOTAAN TRANS JATENG

(Studi Kasus Trans Jateng Koridor I Semarang (Tawang) - Bawen)

(Rr. Citra Aristi Amelia; Edy Mulyantomo; Sugeng Rianto - Universitas Semarang)

WORTHLESSNESS IS A POWER: MENGAPA ORANG BERSEDIA MENARUH UANG DI APLIKASI GO-PAY

(Rahoyo; Rr. Lulus Prapti N.S.S.; Asih Niati - Universitas Semarang).

ANALISIS PENGARUH KUALITAS PRODUK, PERSEPSI HARGA, DAN PROMOSI TERHADAP KEPUTUSAN PEMBELIAN WELLBLUE ALKALINE WATER PITCHER

STRATEGI PEMASARAN UNTUK MENINGKATKAN VOLUME PENJUALAN (STUDI KASUS PADA SHOFA CATERING)

(Wiki Sulistyaningsih; Teguh Ariefiantoro; Edy Suryawardana - Universitas Semarang)

PENGARUH CITRA MEREK, PERSEPSI HARGA, DAN KUALITAS PRODUK TERHADAP KEPUTUSAN PEMBELIAN SEPATU OLAH RAGA MEREK ADIDAS

(Studi di Kota Semarang)

(Rokh Eddy Prabowo; Kis Indriyaningrum; Anggita Dian Setyani - Universitas Stikubank Semarang) .121

PENGARUH KEMUDAHAN TERHADAP KEPUTUSAN MENGGUNAKAN E-BANKING PADA BNI 46 KC KARANGAYU SEMARANG DENGAN MINAT NASABAH DAN KEPERCAYAAN SEBAGAI VARIABEL MEDIASI

(Ahmad Sahri Romadon; Risma Nurhapsari - Universitas Semarang) 
PENELITIAN KEBERLANGSUNGAN USAHA ARDANI INDONESIA SEBAGAI UMKM BERBASIS INDUSTRI KREATIF

(Soegihartono - Universitas Semarang)

STRATEGI PELAYANAN BUS RAPID TRANSIT (BRT) TRANS SEMARANG

(Susanto - Universitas Semarang).....

ANALISIS PENGARUH KEPEMIMPINAN, STRES KERJA, DAN LINGKUNGAN KERJA TERHADAP KINERJA KARYAWAN BAGIAN PRODUKSI SEWING PT. SAMWON BUSANA INDONESIA SEMARANG

(Andana Budi Tami; Sri Yuni Widowati - Universitas Semarang). 


\title{
PENGARUH KEMUDAHAN TERHADAP KEPUTUSAN MENGGUNAKAN E-BANKING PADA BNI 46 KC KARANGAYU SEMARANG DENGAN MINAT NASABAH DAN KEPERCAYAAN SEBAGAI VARIABEL MEDIASI
}

\author{
Ahmad Sahri Romadon \\ Risma Nurhapsari
}

\section{Fakultas Ekonomi Universitas Semarang}

\author{
Diterima: Agustus 2020, Disetujui: September 2020, Dipublikasikan: Oktober 2020
}

\begin{abstract}
The purpose of this study was to determine the effect of convenience on the decision to use E-Banking at BNI 46 KC Karangayu Semarang with customer interest and trust as a mediating variable. The population in this study were all customers registered as E-banking users at Bank BNI 46 KC Karangayu Semarang as many as 44,380 customers (EIS data BNI 46 KC Karangayu Semarang). The sampling technique in this study used Simple Random Sampling technique which is simple random sampling where each unit of analysis gets the same opportunity to be selected as a research sample. The number of samples obtained is 100 respondents (rounded up to represent the population). The analytical method used is testing data instruments, feasibility testing models, classic assumption tests, path analysis (Path Analysis).

Ease of technology has a positive effect on customer interest which can be seen from the significance of $0,000<\alpha=0.05$ and the number $t$ test $=31,684>t$ table $=1,661$. Ease of technology has a positive effect on customer trust which can be seen from the significance of $0,000<\alpha=0,05$ and the number $t$ test $=35,738>t$ table $=1,661$. Ease of technology has a positive effect on decisions using E-Banking which can be seen from the significance of 0,000 < $\alpha=0,05$ and the number $t$ test $=28,490>t$ table $=1,661$. Customer interest has a positive effect on the decision to use E-Banking which can be seen from the significance of $0,000<\alpha=$ 0.05 and the number t test $=42,141>t$ table $=1,661$.

Customer trust has a positive effect on decisions using E-Banking which can be seen from the significance of $0,000<\alpha=0.05$ and the number $t$ test $=45,695>t$ table $=1,661$. Ease of technology has a positive effect on the decision to use E-Banking with customer interest as mediation which can be seen from the significance of $0,000<\alpha=0.05$ and the number $t$ test $=$ 5,177> $t$ table $=1,661$. Ease of technology has a positive effect on the decision to use EBanking with customer trust as a mediation which can be seen from the significance of 0,000 $<\alpha=0.05$ and the number $t$ test $=7.070>$ t table $=1.661$.
\end{abstract}

Keywords : Ease, decision to use E-Banking, customer interest and trust.

Tujuan penelitian ini adalah untuk mengetahui pengaruh kemudahan terhadap keputusan menggunakan E-Banking pada BNI 46 KC Karangayu Semarang dengan minat nasabah dan kepercayaan sebagai variabel mediasi. Populasi dalam penelitian ini adalah seluruh nasabah yang terdaftar sebagai pengguna E-banking di Bank BNI 46 KC Karangayu Semarang sebanyak 44.380 nasabah (data EIS BNI 46 KC Karangayu Semarang). Teknik pengambilan sampel pada penelitian ini digunakan teknik Simple Random Sampling yaitu pengambilan sampel dengan acak sederhana dimana setiap unit analisis memperoleh kesempatan yang sama untuk dipilih sebagai sampel penelitian. Jumlah sampel yang diperoleh adalah 100 responden 
(dibulatkan ke atas agar dapat mewakili jumlah populasi). Metode analisis yang digunakan adalah pengujian instrumen data, uji kelayakan model, uji asumsi klasik, analisis jalur (Path Analysis).

Kemudahan teknologi berpengaruh positif terhadap minat nasabah yang dapat dilihat dari angka signifikansi sebesar $0,000<\alpha=0,05$ dan angka $t$ test $=31,684>t$ tabel $=1,661$. Kemudahan teknologi berpengaruh positif terhadap kepercayaan nasabah yang dapat dilihat dari angka signifikansi sebesar 0,000 $<\alpha=0,05$ dan angka $\mathrm{t}$ test $=35,738>\mathrm{t}$ tabel $=1,661$. Kemudahan teknologi berpengaruh positif terhadap keputusan menggunakan E-Banking yang dapat dilihat dari angka signifikansi sebesar $0,000<\alpha=0,05$ dan angka $t$ test $=28,490>t$ tabel $=1,661$. Minat nasabah berpengaruh positif terhadap keputusan menggunakan E-Banking yang dapat dilihat dari angka signifikansi sebesar $0,000<\alpha=0,05$ dan angka $t$ test $=42,141>t$ tabel $=1,661$.

Kepercayaan nasabah berpengaruh positif terhadap keputusan menggunakan E-Banking yang dapat dilihat dari angka signifikansi sebesar $0,000<\alpha=0,05$ dan angka $\mathrm{t}$ test $=45,695>\mathrm{t}$ tabel $=1,661$. Kemudahan teknologi berpengaruh positif terhadap keputusan menggunakan $E$ Banking dengan minat nasabah sebagai mediasi yang dapat dilihat dari angka signifikansi sebesar $0,000<\alpha=0,05$ dan angka $\mathrm{t}$ test $=5,177>\mathrm{t}$ tabel $=1,661$. Kemudahan teknologi berpengaruh positif terhadap keputusan menggunakan E-Banking dengan kepercayaan nasabah sebagai mediasi yang dapat dilihat dari angka signifikansi sebesar $0,000<\alpha=0,05$ dan angka $t$ test $=7,070>\mathrm{t}$ tabel $=1,661$.

Kata kunci : Kemudahan, keputusan menggunakan E-Banking, minat nasabah dan kepercayaan

\section{PENDAHULUAN}

Pada era globalisasi ini Indonesia telah mengalami perkembangan ekonomi dan teknologi yang pesat. Teknologi informasi sudah merupakan suatu kebutuhan yang sangat penting, bahkan sebagai tuntutan yang mendesak bagi setiap orang untuk menyelesaikan semua permasalahan dengan cepat serta meringankan semua pekerjaannya. Seiring dengan situasi seperti ini, perkembangan teknologi informasi terutama peranan komputer mendapatkan perhatian yang sangat serius. Teknologi informasi ini memberi dampak luar biasa dalam dunia perbankan saat ini. Akhir-akhir ini banyak sekali perubahan pada teknologi informasi, demikian juga di bidang telekomunikasi, kebanyakan disebabkan karena adanya desakan dan dahsyatnya kompetisi di dunia perbankan saat ini. Perkembangan teknologi ini semakin hari semakin pesat, akan tetapi apakah kita siap atau tidak dalam mengikuti perkembangan teknologi tersebut (Firda, 2017).

Banyaknya pengguna internet di Indonesia tentu tidak dapat dipungkiri juga mendorong dunia bisnis untuk lebih maju dan berkembang. Internet menjadi media dalam melakukan transaksi penjualan dan pembelian. Selain itu internet menjadi media untuk mencari informasi dan bertukar informasi. Teknologi juga mendorong dunia perbankan untuk ikut andil dalam memanfaatkan internet. Hal tersebut merupakan kesempatan bagi dunia perbankan untuk melangkah maju dengan memberikan pelayanan yang lebih baik kepada para nasabahnya.Tidak hanya menawarkan kecepatan dalam melakukan transaksi tetapi juga kemudahan serta kenyamanan bagi nasabah untuk melakukan transaksi keuangan maupun non keuangan secara online tanpa mengharuskan nasabahnya untuk datang dan mengantri di bank atau ATM (Widyarini, 2005). 
Layanan E-Banking diberikan oleh bank dengan tujuan utama memberikan kemudahan kepada nasabah. Pelayanan perbankan melalui internet tersebut berupa situs dari suatu bank tertentu yang menyediakan pelayanan perbankan langsung, tanpa perlu datang ke bank yang bersangkutan.Nasabah dapat melakukan cek saldo, mutasi rekening, transfer, pembayaran tagihan, pembelian, dan lain-lain, dimana saja dan kapan saja, asal memiliki koneksi ke internet (Mislah, 2015).

E-Banking memberikan keuntungan bagi beberapa pihak, baik kepada pihak nasabah maupun pihak perbankan itu sendiri. Salah satu keuntungan bagi nasabah yaitu dapat memberikan kemudahan dalam melakukan transaksi perbankan serta menghemat waktu dan biaya. Selain itu, dari sisi pihak perbankan E-Banking dapat meningkatkan kinerja (performance) bank dan biaya untuk memberikan layanan perbankan dapat lebih murah dibandingkan dengan membuka kantor cabang. Namun jika layanan tersebut tidak dimanfaatkan dengan maksimal, maka kesuksesan inovasi teknologi tersebut tidak akan diperoleh. Sebab hal itu secara langsung tergantung dari penerimaan dan persepsi konsumen (nasabah) terhadap teknologi tersebut. Oleh karena itu, penting bagi pihak bank untuk mengetahui bagaimana para nasabah mengapresiasi layanan E-Banking agar dapat membantu menemukan rencana strategis dan meningkatkan pangsa pasar (Mislah, 2015).

Nasabah merupakan pelanggan (customer) baik individu maupun perusahaan yang mendapatkan manfaat atau kegunaan dari produk dan jasa dari sebuah perusahaan perbankan, meliputi kegiatan pembelian, penyewaan, serta layanan jasa.Sedangkan minat merupakan perhatian, kesukaan, kesenangan, ketertarikan (kecocokan hati) kepada sesuatu ataupun keinginan terhadap sesuatu. Oleh sebab itu, perlu adanya keterpaduan baik internal maupun eksternal, baik dalam lingkup proses maupun implementasi, serta keleluasaan dan kedalaman implementasi dari layanan tersebut.

Hasil dari penelitian terdahulu, adanya perbedaan hasil dari penelitian (research gap) yaitu pada penelitian yang dilakukan oleh Syamsul (2014) menyatakan bahwa kemudahan tidak berpengaruh signifikan terhadap minat nasabah dalam menggunakan mobile banking. Sedangkan penelitian yang dilakukan oleh Sri (2009), Widya (2016), Maria (2017) dan Mislah (2015) menyatakan bahwa kemudahan berpengaruh positif dan signifikan terhadap minat menggunakan internet banking. Penelitian ini menggunakan rujukan dari penelitian yang dilakukan oleh Sri (2009) dengan perbedaan dari penelitian sebelumnya adalah pada penelitian sebelumnya hanya menggunakan minat nasabah sebagai variabel mediasi sedangkan pada penelitian ini selain variabel minat nasabah ditambahkannya variabel kepercayaan nasabah sebagai variabel mediasi.

Berdasarkan fenomena di BNI 46 dan research gap di atas maka menarik untuk dilakukan penelitian ulang, peneliti mengusulkan variabel minat dan kepercayaan sebagai variabel mediasi dari pengaruh kemudahan terhadap keputusan menggunakan E-Banking, dengan alasan bahwa kemudahan yang didukung dengan minat dan kepercayaan dari nasabah maka keputusan untuk menggunakan E-Banking akan lebih tinggi. 


\section{TINJAUAN PUSTAKA}

\section{Teori Planned Behavior}

Theory of Planned Behavior adalah teori yang meramalkan pertimbangan perilaku karena perilaku dapat dipertimbangkan dan direncanakan. Kemudian teori ini dikembangkan lagi oleh beberapa peneliti, seperti Ajzen dan Sharma dalam Nuary (2010). Wellington et al (dalam Nuary, 2010) menyatakan Theory of Planned Behavior memiliki keunggulan dibandingkan teori keperilakuan yang lain, karena Theory of Planned Behavior merupakan teori perilaku yang dapat mengidentifikasi keyakinan seseorang terhadap pengendalian atas sesuatu yang akan terjadi dari hasil perilaku, sehingga hal ini membedakan antara perilaku seseorang yang berkehendak dan yang tidak berkehendak.

Menurut Setyobudi (2008) dalam perkembangannya para ahli berkontribusi untuk melengkapi Theory of Planned Behavior dengan berbagai tambahan, diantaranya: ethical obligation, self identity, moral obligation, dan self efficacy.

\section{Teori Reasonable Action}

Teori ini menguhubungkan antara keyakinan (belief), sikap (attitude), kehendak (intention) dan perilaku (behavior). Kehendak merupakan prediktor terbaik perilaku, artinya jika ingin mengetahui apa yang akan dilakukan seseorang, cara terbaik adalah mengetahui kehendak orang tersebut. Namun, seseorang dapat membuat pertimbangan berdasarkan alasan-alasan yang sama sekali berbeda (tidak selalu berdasarkan kehendak). Konsep penting dalam teori ini adalah fokus perhatian (salience), yaitu mempertimbangkan sesuatu yang dianggap penting. Kehendak (intention) ditentukan oleh sikap dan norma subyektif (Jogiyanto, 2007).

Theory of Reasoned Action (TRA) atau teori tindakan beralasan atau teori aksi beralasan mengatakan bahwa sikap mempengaruhi perilaku melalui suatu proses pengambilan keputusan yang teliti dan beralasan, dan dampaknya terbatas hanya pada tiga hal. Pertama, perilaku tidak banyak ditentukan oleh sikap umum tetapi oleh sikap yang spesifik terhadap sesuatu. Kedua, perilaku tidak hanya dipengaruhi oleh sikap tetapi juga oleh norma subyektif (subjective norms) yaitu keyakinan kita mengenai apa yang orang lain inginkan agar kita lakukan. Ketiga, sikap terhadap suatu perilaku bersama-sama norma subyektif membentuk suatu intensi atau niat untuk berperilaku tertentu.

\section{Teori Technology Acceptance Model (TAM)}

Technology Acceptance Model (TAM), yang diperkenalkan oleh Davis pada tahun 1989 adalah suatu adaptasi dari Theory of Reasoned Action (TRA) yang dikhususkan untuk memodelkan penerimaan pemakai (user acceptance) terhadap teknologi. Model ini dikembangkan kembali oleh beberapa peneliti seperti Szajna (1994), Igbaria et al. (1995) dan Venkatesh dan Davis (2000) dalam Jogiyanto (2007). Modifikasi model TAM dilakukan oleh Venkantesh dengan menambahkan variable trust dengan judul Trustenhanced Technology Acceptance Model, yang meneliti tentang hubungan antar variabel TAM dan trust. Modifikasi TAM lain yaitu Trust and Risk in Technology Acceptance Model (TRITAM) dilakukan oleh Lui and Jamieson dalam Jogiyanto (2007) menggunakan variabel kepercayaan dan resiko bersama variabel TAM. 
Beberapa model penelitian telah dilakukan untuk menganalisis dan memahami faktor-faktor yang mempengaruhi diterimanya penggunaan teknologi komputer, diantaranya yang tercatat dalam berbagai literatur dan referensi hasil riset di bidang teknologi informasi adalah seperti TRA, Theory of Planed Behaviour (TPB), dan TAM yang dikembangkan oleh Davis et al dalam Jogiyanto (2007) merupakan salah satu model penelitian yang paling banyak digunakan dalam penelitian teknologi informasi, karena model penelitian ini lebih sederhana dan mudah diterapkan.

\section{Internet Banking}

Internet banking yang juga dikenal dengan istilah online banking atau e-banking ini menurut situs wikipedia adalah melakukan transaksi, pembayaran, dan transaksi lainnya melalui internet dengan website milik bank yang dilengkapi sistem keamanan. Dari waktu ke waktu, makin banyak bank yang menyediakan layanan atau jasa internet banking. Aplikasi teknologi informasi dalam internet banking akan meningkatkan efisiensi, efektifitas, dan produktifitas sekaligus meningkatkan pendapatan melalui sistem penjualan yang jauh lebih efektif daripada bank konvensional. Tanpa adanya aplikasi teknologi informasi dalam internet banking, maka internet banking tidak akan jalan dan dimanfaatkan oleh industri perbankan.

\section{Perilaku Konsumen}

Menurut Kotler dan Keller (2009:166) perilaku konsumen adalah studi tentang bagaimana individu, kelompok, dan organisasi memlih, membeli, menggunakan, dan bagaimana barang, jasa, ide, atau pengalaman untuk memuaskan kebutuhan dan keinginan mereka. Studi perilaku konsumen terpusat pada cara individu mengambil keputusan untuk memanfaatkan sumber daya mereka yang tersedia (waktu, uang, usaha) guna membeli barang-barang yang berhubungan dengan konsumsi. Hal ini mencakup apayang mereka beli, mengapamereka membeli,kapan mereka membeli, dimanamereka membeli, seberapa seringmereka membeli, dan seberapa sering mereka menggunakannya.

\section{Kemudahan Penggunaan}

Menurut Davis (2011 : 320) pengertian persepsi kemudahan penggunaan, didefinisikan sebagai tingkat dimana seseorang meyakini bahwa penggunaan teknologi informasi merupakan hal yang mudah dan tidak memerlukan usaha keras dari pemakainya. Konsep ini mencakup kejelasan tujuan penggunaan TI dan kemudahaan penggunaan sistem untuk tujuan sesuai dengan keinginan pemakai. Dalam TAM, faktor persepsi terhadap kemudahan untuk menggunakan teknologi dan persepsi terhadap daya guna sebuat teknologi berhubungan dengan sikap seseorang pada penggunaan teknologi tersebut. Sikap pada penggunaan sesuatu adalah sikap suka atau tidak suka terhadap penggunaan suatu produk. Sikap suka atau tidak suka terhadap suatu produk ini dapat digunakan untuk memprediksi perilaku niat seseorang untuk menggunakan suatu produk atau tidak menggunakannya.

\section{Kepercayaan}

Dooney dan Cannon (dikutip oleh Kusmayadi, 2017:182) berpendapat dimana kepercayaan muncul ketika adanya keyakinan dari pihak konsumen yaitu pelanggan pada reliabilitas dan integritas dari rekan pertukaran. Kepercayaan disini adalah 
kepercayaan nasabah pada penyelenggara transaksi elektronik perbankan, serta kepercayaan pada mekanisme operasional dari transaksi yang dilakukan.

\section{Kerangka Pemikiran}

Berdasarkan uraian di atas, maka dibuat kerangka pemikiran sebagai berikut:

\section{Gambar 1. Kerangka Pemikiran Teoritis}

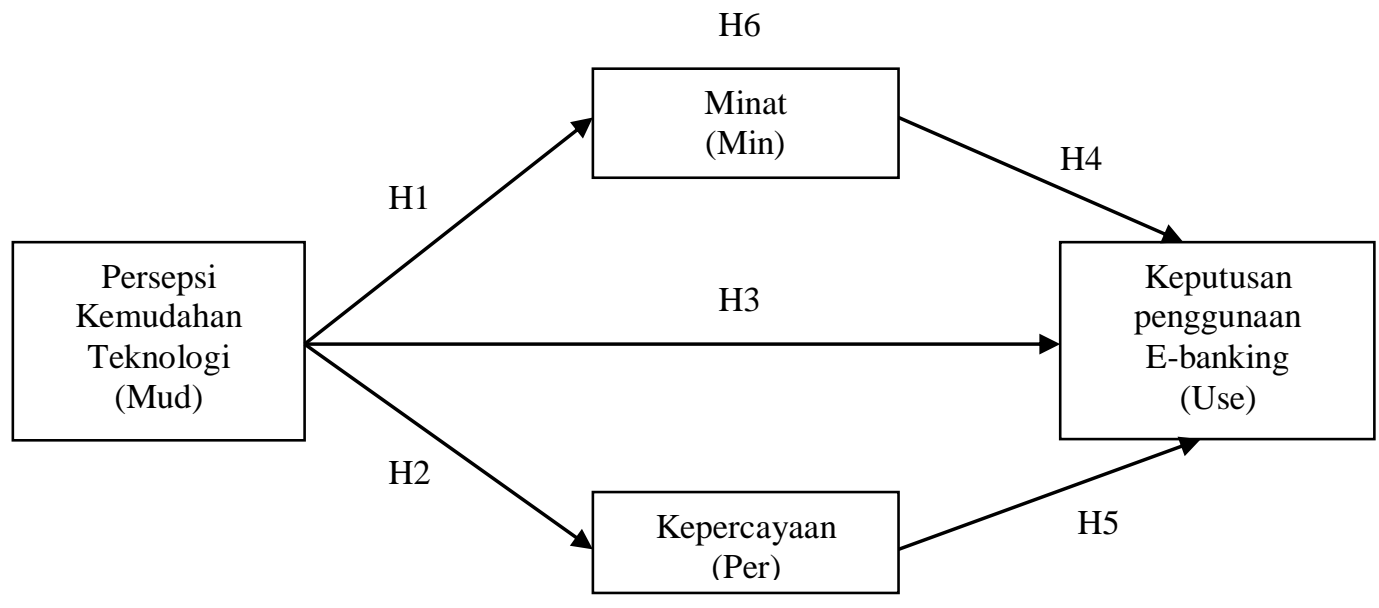

$\mathrm{H} 7$

\section{Pengaruh Persepsi Kemudahan Teknologi terhadap Minat Nasabah}

Persepsi kemudahan memberikan indikasi bahwa suatu sistem dirancang bukan untuk menyulitkan pemakainya, tetapi justru mempermudah seseorang dalam menyelesaikan pekerjaannya. Dengan kata lain, seseorang yang menggunakan sistem akan bekerja lebih mudah dibandingkan dengan seseorang yang tidak menggunakan sistem atau bekerja secara manual.

Intensitas penggunaan dan interaksi pengguna dengan sistem juga dapat menunjukkan kemudahan penggunaan. Suatu sistem yang lebih sering digunakan dapat menunjukkan bahwa sistem tersebut lebih dikenal, lebih mudah dioperasikan, dan lebih mudah digunakan oleh pemakainya. Kemudahan penggunaan menjadi faktor penting bagi nasabah untuk menerima dan berminat dengan sistem E-banking yang ditawarkan tersebut.

Penelitian yang dilakukan oleh Sri (2009) menyatakan bahwa kemudahan berpengaruh positif dan signifikan terhadap minat nasabah menggunakan E-banking. Hasil tersebut didukung oleh penelitian Maria (2017), Mislah (2015) dan Fita (2013).

$\mathrm{H}_{1} \quad$ : Persepsi kemudahan teknologiberpengaruh positif terhadap minat nasabah

\section{Pengaruh Persepsi Kemudahan Teknologi terhadap Kepercayaan Nasabah}

Persepsi kemudahan teknologi dalam penggunaan E-banking memiliki makna bahwa layanan E-banking akan mudah dipahami dan mudah untuk digunakan, sehingga nasabah dapat dengan mudah mempelajari tata cara bertransaksi menggunakan $E$ banking. Penerimaan penggunaan sebuah sistem juga turut dipengaruhi oleh kemudahan 
penggunaan sistem tersebut. Hal ini merupakan refleksi psikologis pengguna untuk lebih bersikap terbuka terhadap sesuatu yang mudah dipahami. Kemudahan tersebut dapat mendorong seseorang untuk menerima dan menggunakan sebuah sistem.

Kemudahan penggunaan ini juga merupakan suatu kepercayaan tentang proses pengambilan keputusan. Jika seseorang merasa percaya bahwa sistem informasi mudah digunakan maka dia akan menggunakannya. Sebaliknya jika seseorang merasa percaya bahwa sistem informasi tidak mudah digunakan maka dia tidak akan menggunakannya.

Penelitian yang dilakukan oleh Fita (2013) yang menyatakan bahwa kemudahaan penggunaan berpengaruh positif terhadap kepercayaan nasabah dalam menggunakan internet banking. Berdasarkan teori dan penelitian terdahulu, maka dapat disusun hipotesis sebagai berikut:

$\mathrm{H}_{2} \quad$ : Persepsi kemudahan teknologi berpengaruh positif terhadap kepercayaan nasabah.

\section{Pengaruh Persepsi Kemudahan Teknologi terhadap Keputusan Menggunakan E- Banking}

Persepsi kemudahan penggunaan diyakini memiliki pengaruh yang kuat dalam pembentukan sikap seorang individu dalam menerima sebuah teknologi. Davis (2011) memberikan beberapa indikator kemudahan terhadap suatu sistem informasi (termasuk E-banking) yaitu mudah dipelajari dan dioperasikan, mengerjakan dengan mudah apa yang diinginkan oleh pengguna, dan menambah keterampilan para pengguna. Semakin mudah suatu sistem untuk dipelajari dan digunakan, maka hal tersebut akan meningkatkan keputusan nasabah untuk menggunakan E-banking.

Penelitian yang dilakukan oleh Firda (2017) yang menyatakan bahwa kemudahan penggunaan berpengaruh positif terhadap adopsi internet banking BNI. Berdasarkan teori dan penelitian terdahulu, maka dapat disusun hipotesis sebagai berikut:

$\mathrm{H}_{3}$ : Persepsi kemudahan teknologi berpengaruh positif terhadap keputusan menggunakan E-Banking.

\section{Pengaruh Minat Nasabah terhadap Keputusan Menggunakan $\boldsymbol{E}$-Banking}

Minat adalah kecenderungan tertarik pada sesuatu yang relatif tetap untuk lebih memperhatikan dan mengingat secara terus menerus yang diikuti rasa senang untuk memperoleh sesuatu kepuasan dalam mencapai kepuasaan penggunaan teknologi. Apabila kepuasan tersebut telah dirasakan manfaatnya, maka seseorang akan secara kontinuitas menggunakan.

Keputusan merupakan pemilihan satu di antara banyak pilihan dari alternatif yang ada. Pada umumnya keputusan dibuat dalam rangka untuk memecahkan masalah atau persoalan. Keputusan menggunakan adalah titik dalam perumusan berbagai alternatif tindakan yang sesuai dengan yang sedang diperhatikan dan memilih dari berbagai macam alternatif yang tepat setelah melakukan evaluasi atau penilaian agar dapat menggunakannya untuk memperoleh manfaat yang ditawarkannya (Fita, 2013).

E-Banking adalah jasa dan produk bank secara langsung kepada nasabah melalui elektronik dan saluran komunikasi internet. Nasabah tidak perlu berlama-lama mengantri di bank, cukup bermodalkan handphone dan koneksi internet para nasabah dapat melakukan transaksi. Dari minat adalah kecenderungan tertarik pada sesuatu yang relatif tetap untuk lebih memperhatikan dan mengingat secara terus menerusyang diikuti rasa senang setelah melakukan keputusan dalam menggunakan teknologi E-banking. 
Penelitian yang dilakukan oleh Sri (2009) menyatakan bahwa minat nasabah berpengaruh positif dan signifikan terhadap keputusan dalam bertransaksi dengan $E$ Banking. Berdasarkan teori dan penelitian terdahulu, maka dapat disusun hipotesis sebagai berikut:

$\mathrm{H}_{4} \quad$ : Minat nasabah berpengaruh positif terhadap keputusan menggunakan EBanking.

\section{Pengaruh Kepercayaan terhadap Keputusan Menggunakan E-Banking}

Sikap nasabah menggunakan E-banking didorong oleh rasa kepercayaan yang berperan penting untuk meningkatkan kegunaan dalam lingkungan E-banking. Kepercayaan menjadi lebih penting dalam dunia online jika dibandingkan dengan offline banking karena transaksi dalam online banking mengandung informasi yang sensitif dan pihak yang terlibat dalam transaksi keuangan mengkhawatirkan akses terhadap file penting dan informasi yang dikirim melalui internet. Dengan demikian jika seseorang merasa percaya dengan sistem E-Banking yang digunakan maka dia akan menggunakannya.

Penelitian yang dilakukan oleh Firda (2017) yang menyatakan bahwa kepercayaan berpengaruh terhadap sikap dalam penggunaan mobile banking. Berdasarkan teori dan penelitian terdahulu, maka dapat disusun hipotesis sebagai berikut:

$\mathrm{H}_{5}$ : Kepercayaan berpengaruh positif terhadap keputusan menggunakan EBanking.

\section{Pengaruh Persepsi Kemudahan Teknologi terhadap Keputusan Menggunakan $E$ - Banking Dengan Minat Nasabah Sebagai Variabel Mediasi}

Manfaat dari E-Banking bagi nasabah meliputi membuat pekerjaan lebih mudah, menambah produktivitas, mempertinggi efektivitas, dan mengembangkan kinerja pekerjaan. Kemanfaatan yang meningkatkan kinerja akan berdampak terhadap minat penggunaan teknologi. Minat nasabah dalam menggunakan E-Banking dapat meningkatkan hubungan antara kemudahan sistem yang ditawarkan dengan keputusan nasabah dalam bertransaksi menggunakan E-banking.

Penelitian yang dilakukan oleh Sri (2009) menyatakan bahwa kemudahan berpengaruh positif dan signifikan terhadap minat nasabah menggunakan e-banking. Hasil tersebut didukung oleh penelitian Maria (2017), Mislah (2015) dan Fita (2013). Penelitian yang dilakukan oleh Sri (2009) menyatakan bahwa minat nasabah dapat memediasi hubungan antara perceived easy of use (kemudahan) dengan keputusan dalam bertransaksi dengan internet banking.Berdasarkan teori dan penelitian terdahulu, maka dapat disusun hipotesis sebagai berikut:

$\mathrm{H}_{6}$ : Persepsi kemudahan teknologi berpengaruh positif terhadap keputusan menggunakanE-Banking dengan minat nasabah sebagai variabel mediasi.

\section{Pengaruh Persepsi Kemudahan Teknologi terhadap Keputusan Menggunakan $E$ - Banking Dengan Kepercayaan Sebagai Variabel Mediasi}

Kemudahan pengguna merupakan sejauhmana seseorang percaya bahwa menggunakan suatu teknologi akan bebas dari usaha. Kemudahan penggunaan akan mengurangi usaha (baik waktu dan tenaga) seseorang di dalam mempelajari komputer. Pengguna TI mempercayai bahwa TI yang lebih fleksibel, mudah dipahami dan mudah pengoperasiannya (compatible) sebagai karakteristik kemudahan penggunaan. Dengan 
kepercayaan nasabah tersebut terhadap kemudahan teknologi E-banking, maka dapatmeningkatkan keputusan nasabah dalam menggunakan teknologi tersebut.

Penelitian yang dilakukan oleh Fita (2013) yang menyatakan bahwa kemudahaan penggunaan berpengaruh positif terhadap kepercayaan nasabah dalam menggunakan internet banking. Penelitian yang dilakukan oleh Firda (2017) yang menyatakan bahwa kepercayaan berpengaruh terhadap sikap dalam penggunaan mobile banking. Berdasarkan teori dan penelitian terdahulu, maka dapat disusun hipotesis sebagai berikut:

$\mathrm{H}_{7}$ : Persepsi kemudahan teknologi berpengaruh positif terhadap keputusan menggunakan E-Banking dengan kepercayaan sebagai variabel mediasi.

\section{METODE PENELITIAN}

Populasi dalam penelitian ini adalah seluruh nasabah yang terdaftar sebagai pengguna E-banking di Bank BNI 46 KC Karangayu Semarang sebanyak 44.380 nasabah (data EIS BNI 46 KC Karangayu Semarang). Teknik pengambilan sampel pada penelitian ini digunakan teknik Simple Random Sampling yaitu pengambilan sampel dengan acak sederhana dimana setiap unit analisis memperoleh kesempatan yang sama untuk dipilih sebagai sampel penelitian. Jumlah sampel yang diperoleh adalah 100 responden (dibulatkan ke atas agar dapat mewakili jumlah populasi). Setelah dilakukan pengolahan data SPSS terdapat 6 data extrim yaitu:

a) Persamaan I : Responden No.51

b) Persamaan II: Responden No. 52 dan 84

c) Persamaan III : Responden No. 44,48 dan 56

Sehingga data valid yang diolah menjadi 94 responden.

Metode analisis yang digunakan adalah pengujian instrumen data, uji kelayakan model, uji asumsi klasik, analisis jalur (Path Analysis). Analisis jalur digunakan untuk menguji hipotesis analisis faktor-faktor yang mempengaruhi keputusan penggunaan $E$ Banking pada BNI 46 KC Karangayu Semarang dengan minat nasabah sebagai variabel interveningdengan langkah-langkah sebagai berikut :

a. Menentukan persamaan struktural. yaitu terdiri atas tiga persamaan struktural, yaitu:

Min $=b_{1}$ MudX1+ $e_{1}$

Per $=b_{2} \operatorname{Mud~} \mathrm{X}_{2}+\mathrm{e}_{2}$

Use $=b_{3}$ Mud $+b_{4}$ Min $+b_{5}$ Per $+e_{3}$

b. Penafsiran hasil untuk substruktur

Untuk melihat besarnya pengaruh variabel keefektifan pengendalian internal dan kesesuaian kompensasi terhadap perilaku tidak etis dan pengaruh variabel keefektifan pengendalian internal, ketaatan aturan akuntansi kesesuaian kompensasi dan perilaku tidak etis terhadap kecenderungan kecurangan akuntansi secara sendirisendiri/parsial, digunakan Uji T. Sementara untuk melihat besarnya pengaruh, digunakan angka Beta atau Standardized Coeffecient. Langkah-langkah dalam menguji hipotesis adalah :

1) Menentukan hipotesis yaitu Ho dan $\mathrm{H}_{1}$

2) Menghitung besarnya t penelitian. Besarnya $t$ penelitian terdapat pada hasil perhitungan SPSS (tabel Coefficients).

3) Menghitung besarnya angka $t$ tabel dengan ketentuan sebagai berikut :

Tarif signifikan 0,05 dan Derajat Kebebasan (DK) dengan ketentuan: DK $=\mathrm{n}-2$ (Jonathan Sarwono, 2007:30) 
4) Menentukan kriteria

Kriteria uji hipotesisnya sebagai berikut :

Jika t penelitian > t tabel, maka $\mathrm{H} 0$ ditolak dan $\mathrm{H} 1$ diterima

Jika t penelitian < t tabel, maka H0 diterima dan H1 ditolak

(Jonathan Sarwono, 2007:30)

5) Membuat keputusan apakah terdapat pengaruh dari masing-masing variabel.

c. Menentukan kesimpulan-kesimpulan dari penelitian ini mengenai analisis faktorfaktor yang mempengaruhi keputusan penggunaan E-Banking pada BNI $46 \mathrm{KC}$ Karangayu Semarang dengan minat nasabah sebagai variabel mediasi.

Suatu variabel dapat disebut sebagai variabel mediator apabila variabel tersebut ikut mempengaruhi hubungan antara variabel independen dan variabel dependen. Pengujian hipotesis dilakukan dengan prosedur causal steps yang dikembangkan oleh Baron dan Kenny (1986 dalam Andanawari 2013). Dalam pengujian causal steps, peneliti harus mengestimasi tiga persamaan regresi sebagai berikut :

a. Persamaan regresi sederhana variabel mediator $(M)$ pada variabel independen $(X)$.

b. Persamaan regresi sederhana variabel dependen (Y) pada variabel independen (X).

c. Persamaan regresi berganda variabel dependen $(\mathrm{Y})$ pada kedua variabel independen (X) dan variabel mediator (M).

Pengujian hipotesis mediasi dapat dilakukan dengan prosedur Uji Sobel (Sobel Test) yang dikembangkan oleh Sobel (Andanawari, 2013). Uji Sobel dilakukan dengan cara menguji kekuatan pengaruh tidak langsung variabel independen (X) kepada variabel dependen $(\mathrm{Y})$ melalui variabel mediator $(\mathrm{M})$. Pengaruh tidak langsung $\mathrm{X}$ ke $\mathrm{Y}$ melalui $\mathrm{M}$ dihitung dengan cara mengalikan jalur $\mathrm{X} \rightarrow \mathrm{M}$ (a) dengan jalur $\mathrm{M} \rightarrow \mathrm{Y}$ (b) atau $a b$. Jadi koefisien $a b=\left(c^{-} c^{\prime}\right)$, dimana $\mathrm{c}$ adalah pengaruh $\mathrm{X}$ terhadap $\mathrm{Y}$ tanpa mengontrol $\mathrm{M}$, dan c' adalah koefisien pengaruh $\mathrm{X}$ terhadap $\mathrm{Y}$ setelah mengontrol $\mathrm{M}$. Persamaan Uji Sobel adalah sebagai berikut :

$\mathrm{Sab}=\sqrt{\mathrm{b}^{2} \mathrm{Sa}^{2}+\mathrm{a}^{2} \mathrm{Sb}^{2}+\mathrm{Sa}^{2} \mathrm{Sb}^{2}}$

\section{HASIL DAN PEMBAHASAN}

\section{Pengujian Instrumen}

\section{Uji Validitas}

Uji validitas pada penelitian ini menggunakan korelasi Product Moment, jika hasil pengamatan $\mathrm{r}$ hitung $>\mathrm{r}$ tabel, maka kuesioner valid atau sahih. Adapun hasil perhitungan dengan bantuan program SPSS (Stastitical Package for Social Science) Versi 23.0 adalah sebagai berikut :

a. Uji validitas variabel persepsi kemudahan teknologi

Tabel 4.16.

Uji Validitas Variabel Persepsi Kemudahan Teknologi

\begin{tabular}{|c|c|c|r|}
\hline Butir & r hitung & r tabel & Keterangan \\
\hline Mud1 & 0,791 & 0,199 & Valid \\
\hline Mud2 & 0,743 & 0,199 & Valid \\
\hline Mud3 & 0,737 & 0,199 & Valid \\
\hline
\end{tabular}

Sumber : Data primer yang diolah, 2018 
Berdasarkan tabel 4.16. dapat diketahui semua $\mathrm{r}$ hitung dari peryataan Mud1 sampai dengan Mud3 (Corected Item Total Correlation) $>$ angka $\mathrm{r}$ tabel $(\mathrm{df}=\mathrm{n}-2=100-2=98)=0,199$, sehingga semua data adalah valid.

b. Uji validitas variabel keputusan menggunakan E-Banking

Tabel 4.17.

Uji Validitas Variabel Keputusan Menggunakan E-Banking

\begin{tabular}{|c|c|c|r|}
\hline Butir & r hitung & r tabel & Keterangan \\
\hline Use 1 & 0,936 & 0,199 & Valid \\
\hline Use 2 & 0,859 & 0,199 & Valid \\
\hline Use 3 & 0,924 & 0,199 & Valid \\
\hline
\end{tabular}

Sumber : Data primer yang diolah, 2018

Berdasarkan tabel 4.17. dapat diketahui semua $r$ hitung dari pernyataan Use1 sampai dengan Use3 (Corected Item Total Correlation) $>$ angka $\mathrm{r}$ tabel ( $\mathrm{df}$ $=\mathrm{n}-2=100-2=98)=0,199$, sehingga semua data adalah valid.

c. Uji validitas variabel minat nasabah

Tabel 4.18.

Uji Validitas Variabel Minat Nasabah

\begin{tabular}{|c|c|c|r|}
\hline Butir & r hitung & r tabel & Keterangan \\
\hline Min1 & 0,934 & 0,199 & Valid \\
\hline Min2 & 0,797 & 0,199 & Valid \\
\hline Min3 & 0,901 & 0,199 & Valid \\
\hline
\end{tabular}

Sumber : Data primer yang diolah, 2018

Berdasarkan tabel 4.18. dapat diketahui semua $r$ hitung dari pernyataan Min1 sampai dengan Min3 (Corected Item Total Correlation) $>$ angka $\mathrm{r}$ tabel ( $\mathrm{df}$ $=\mathrm{n}-2=100-2=98)=0,199$, sehingga semua data adalah valid.

d. Uji validitas variabel kepercayaan nasabah

Tabel 4.19.

Uji Validitas Variabel Kepercayaan Nasabah

\begin{tabular}{|c|c|c|r|}
\hline Butir & r hitung & r table & Keterangan \\
\hline Per1 & 0,856 & 0,199 & Valid \\
\hline Per2 & 0,823 & 0,199 & Valid \\
\hline Per3 & 0,916 & 0,199 & Valid \\
\hline
\end{tabular}


Sumber : Data primer yang diolah, 2018

Berdasarkan tabel 4.19. dapat diketahui semua $\mathrm{r}$ hitung dari pernyataan Per1 sampai dengan Per3 (Corected Item Total Correlation) $>$ angka $\mathrm{r}$ tabel ( $\mathrm{df}$ $=\mathrm{n}-2=100-2=98)=0,199$, sehingga semua data dianggap valid.

\section{Uji Reliabilitas}

Uji reliabilitas pada pengujian ini menggunakan Cronbach Alpa, jika Cronbach Alpha > 0,7 maka kuesioner dikatakan konsisten atau reliabel. Berdasarkan perhitungan dengan program SPSS Versi 23.0 masing-masing variabel nilai alpha nampak pada tabel dibawah ini, maka kuesioner dalam penelitian ini adalah konsisten atau reliabel.

Tabel 4.20.

Uji Reliabilitas Data

\begin{tabular}{|c|l|c|c|}
\hline No. & \multicolumn{1}{|c|}{ Variabel } & Alpha Cronbach & Keterangan \\
\hline 1 & Persepsi Kemudahan Teknologi & 0,871 & Reliabel \\
\hline 2 & Keputusan Menggunakan E-Banking & 0,955 & Reliabel \\
\hline 3 & Minat Nasabah & 0,940 & Reliabel \\
\hline 4 & Kepercayaan Nasabah & 0,933 & Reliabel \\
\hline
\end{tabular}

Sumber : Data primer yang diolah, 2018

\section{Analisis Jalur (Path Analysis)}

\section{Persamaan Persepsi Kemudahan Teknologi terhadap Minat Nasabah}

\section{Uji Fit Model}

a. Uji F test

Tabel 4.21.

Uji F-test

ANOVA $^{\mathrm{b}}$

\begin{tabular}{|ll|r|r|r|r|r|}
\hline Model & & Sum of Squares & df & Mean Square & F & \multicolumn{1}{c|}{ Sig. } \\
\hline 1 & Regression & 1023.793 & 1 & 1023.793 & $1.253 \mathrm{E} 3$ & $.000^{\mathrm{a}}$ \\
& Residual & 75.186 & 92 & .817 & & \\
& Total & 1098.979 & 93 & & & \\
\hline
\end{tabular}

a. Predictors: (Constant), Persepsi kemudahan teknologi

b. Dependent Variable: Minat nasabah

Sumber : Data primer yang diolah, 2018

Berdasarkan hasil perhitungan dengan bantuan program SPSS Versi 23.0 diketahui angka signifikansi uji F-test sebesar $0,000<\alpha=0,05$ sehingga signifikan. Sedangkan nilai F test sebesar 1253> F tabel sebesar 2,70 $(\alpha=0,05$, Numerator (jumlah variabel -1$)=4-1=3$ dan Denumerator $(n-2)=94-2=$ 92). Hal ini berarti bahwa model regresi persepsi kemudahan teknologi dapat digunakan untuk memprediksi perubahan variabel dependen (minat nasabah). 


\section{b. Koefisien Determinasi}

Tabel 4.22.

Koefisien Determinasi

\begin{tabular}{|l|r|r|r|r|r|}
\hline Model & $\mathrm{R}$ & R Square & $\begin{array}{c}\text { Adjusted R } \\
\text { Square }\end{array}$ & $\begin{array}{c}\text { Std. Error of the } \\
\text { Estimate }\end{array}$ & Durbin-Watson \\
\hline 1 & $.965^{\mathrm{a}}$ & .932 & .931 & .904 & 2.098 \\
\hline
\end{tabular}

Sumber : Data primer yang diolah, 2018

Berdasarkan hasil perhitungan program SPSS Versi 23.0 diperoleh nilai $R$ Square sebesar 0,931 yang berarti bahwa 93,1\% variasi variabel minat nasabah dipengaruhi oleh variabel persepsi kemudahan teknologi. Sedangkan sisanya $6,9 \%$ variasi variabel minat nasabah dipengaruhi oleh variabel lain yang tidak termasuk dalam penelitian ini.

\section{Uji Asumsi Klasik}

a. Uji Multikolinearitas

Hasil yang diperoleh dalam angka VIF untuk variabel persepsi kemudahan teknologi sebesar 1,000 $<10$, maka data penelitian digolongkan tidak terdapat gangguan multikolinearitas dalam model regresinya.

b. Uji Heteroskedastisitas

Gambar Scatterplot, menunjukkan titik-titik yang terbentuk menyebar secara acak dan tersebar baik di atas maupun di bawah angka 0 pada sumbu $\mathrm{Y}$, hal ini dapat disimpulkan bahwa tidak terjadi heteroskedastisitas pada model regresi, sehingga model regresi layak dipakai.

c. Uji Autokorelasi

Nilai Durbin-Watson yang diperoleh dalam pengujian ini adalah 2,098 yang dibandingkan dengan nilai tabel DW dengan nilai signifikansi 0,05, jumlah sampel $94(\mathrm{n}=94)$ dan jumlah variabel independen $1(\mathrm{k}=1)$, maka dari tabel DW didapatkan nilai batas bawah (dL) adalah 1,6427 dan nilai batas atas (dU) adalah 1,6857 dan 4-dU = 2,3143. Nilai DW 2,098 sehingga $2<2,098<2,3143$. Hal ini menunjukkan bahwa tidak ada autokorelasi sehingga model regresi layak digunakan.

d. Uji Normalitas

Pada gambar normal probability plot maupun gambar histrogram dapat disimpulkan bahwa gambar histrogram memberikan pola distribusi yang mendekati normal. Sedangkan pada gambar normal probability plot terlihat titiktitik penyebar di sekitar garis diagonal, serta penyebaran mengikuti arah garis diagonal. Kedua grafik ini menunjukkan bahwa modal regresi layak dipakai karena memenuhi asumsi normalitas. 


\section{Persamaan Persepsi Kemudahan Teknologi terhadap Kepercayaan Nasabah}

\section{Uji Fit Model}

a. Uji F test

Tabel 4.25.

Uji F-test

ANOVA $^{\mathrm{b}}$

\begin{tabular}{|ll|r|r|r|r|r|}
\hline Model & Sum of Squares & df & Mean Square & F & Sig. \\
\hline 1 & Regression & 1003.346 & 1 & 1003.346 & $1.466 \mathrm{E} 3$ & $.000^{\mathrm{a}}$ \\
& Residual & 62.963 & 92 & .684 & & \\
& Total & 1066.309 & 93 & & & \\
\hline
\end{tabular}

a. Predictors: (Constant), Persepsi kemudahan teknologi

b. Dependent Variable: Kepercayaan nasabah

Sumber : Data primer yang diolah, 2018

Berdasarkan hasil perhitungan dengan bantuan program SPSS Versi 23.0 diketahui angka signifikansi uji F-test sebesar $0,000<\alpha=0,05$ sehingga signifikan. Sedangkan nilai F test sebesar 1466> F tabel sebesar 2,70 $(\square=0,05$, Numerator (jumlah variabel -1$)=4-1=3$ dan Denumerator $(n-2)=94-2=$ 92). Hal ini berarti bahwa model regresi persepsi kemudahan teknologi dapat digunakan untuk memprediksi perubahan variabel dependen (kepercayaan nasabah).

b. Koefisien Determinasi

Tabel 4.26.

Koefisien Determinasi

Model Summaryb

\begin{tabular}{|l|r|r|r|r|r|}
\hline Model & $\mathrm{R}$ & R Square & \multicolumn{1}{|c|}{$\begin{array}{c}\text { Adjusted R } \\
\text { Square }\end{array}$} & $\begin{array}{c}\text { Std. Error of the } \\
\text { Estimate }\end{array}$ & Durbin-Watson \\
\hline 1 & $.970^{\mathrm{a}}$ & .941 & .940 & .827 & 2.279 \\
\hline
\end{tabular}

a. Predictors: (Constant), Persepsi kemudahan teknologi

b. Dependent Variable: Kepercayaan nasabah

Sumber : Data primer yang diolah, 2018

Berdasarkan hasil perhitungan program SPSS Versi 23.0 diperoleh nilai $R$ Square sebesar 0,940 yang berarti bahwa 94,0 variasi variabel kepercayaan nasabah dipengaruhi oleh variabel persepsi kemudahan teknologi. Sedangkan sisanya $6,0 \%$ variasi variabel kepercayaan nasabah dipengaruhi oleh variabel lain yang tidak termasuk dalam penelitian ini.

\section{Uji Asumsi Klasik}

a. Uji Multikolinearitas

Hasil yang diperoleh dalam angka VIF untuk variabel persepsi kemudahan teknologi sebesar 1,000 $<10$, maka data penelitian digolongkan tidak terdapat gangguan multikolinearitas dalam model regresinya.

b. Uji Heteroskedastisitas

Gambar Scatterplot, menunjukkan titik-titik yang terbentuk menyebar secara acak dan tersebar baik di atas maupun di bawah angka 0 pada sumbu $Y$, hal ini 
dapat disimpulkan bahwa tidak terjadi heteroskedastisitas pada model regresi, sehingga model regresi layak dipakai.

c. Uji Autokorelasi

Nilai Durbin-Watson yang diperoleh dalam pengujian ini adalah 2,279 yang dibandingkan dengan nilai tabel DW dengan nilai signifikansi 0,05, jumlah sampel $94(\mathrm{n}=94)$ dan jumlah variabel independen $1(\mathrm{k}=1)$, maka dari tabel DW didapatkan nilai batas bawah (dL) adalah 1,6427 dan nilai batas atas (dU) adalah 1,6857 dan 4-dU =2,3143. Nilai DW 2,279 sehingga $2<2,279<2,3143$. Hal ini menunjukkan bahwa tidak ada autokorelasi sehingga model regresi layak digunakan.

d. Uji Normalitas

Pada gambar normal probability plot maupun gambar histrogram dapat disimpulkan bahwa gambar histrogram memberikan pola distribusi yang mendekati normal. Sedangkan pada gambar normal probability plot terlihat titiktitik penyebar di sekitar garis diagonal, serta penyebaran mengikuti arah garis diagonal. Kedua grafik ini menunjukkan bahwa modal regresi layak dipakai karena memenuhi asumsi normalitas.

\section{Persamaan Persepsi Kemudahan Teknologi terhadap Keputusan Menggunakan E- Banking}

\section{Uji Fit Model}

a. Uji F test

Tabel 4.29.

Uji F-test

ANOVA $^{b}$

\begin{tabular}{|ll|r|r|r|r|r|}
\hline Model & & Sum of Squares & df & Mean Square & \multicolumn{1}{c|}{ F } & \multicolumn{1}{c|}{ Sig. } \\
\hline 1 & Regression & 1092.321 & 3 & 364.107 & $1.720 \mathrm{E} 3$ & $.000^{\mathrm{a}}$ \\
& Residual & 19.051 & 90 & .212 & & \\
& Total & 1111.372 & 93 & & & \\
\hline
\end{tabular}

a. Predictors: (Constant), Kepercayaan nasabah, Persepsi kemudahan teknologi, Minat nasabah

b. Dependent Variable: Keputusan menggunakan E-Banking

Sumber : Data primer yang diolah, 2018

Berdasarkan hasil perhitungan dengan bantuan program SPSS Versi 23.0 diketahui angka signifikansi uji F-test sebesar $0,000<\alpha=0,05$ sehingga signifikan. Sedangkan nilai $\quad F$ test sebesar $1720>$ F tabel sebesar 2,70 ( $\square=0,05$, Numerator (jumlah variabel - 1) $=4-1=3$ dan Denumerator $(n-2)$ $=94-2$ =92). Hal ini berarti bahwa model regresi persepsi kemudahan teknologi, minat nasabah dan kepercayaan nasabah dapat digunakan untuk memprediksi perubahan variabel dependen (keputusan menggunakan EBanking). 


\section{b. Koefisien Determinasi}

\section{Tabel 4.30.}

Koefisien Determinasi

Model Summary ${ }^{b}$

\begin{tabular}{l|r|r|r|r|r|}
\hline Model & $\mathrm{R}$ & $\mathrm{R}$ Square & $\begin{array}{c}\text { Adjusted R } \\
\text { Square }\end{array}$ & $\begin{array}{c}\text { Std. Error of the } \\
\text { Estimate }\end{array}$ & Durbin-Watson \\
\hline 1 & $.991 \mathrm{a}$ & .983 & .982 & .460 & 1.670 \\
\hline
\end{tabular}
a. Predictors: (Constant), Kepercayaan nasabah, Persepsi kemudahan teknologi, Minat
nasabah
b. Dependent Variable: Keputusan menggunakan E-Banking

Sumber : Data primer yang diolah, 2018

Berdasarkan hasil perhitungan program SPSS Versi 23.0 diperoleh nilai $R$ Square sebesar 0,982 yang berarti bahwa 98,2 variasi variabel keputusan menggunakan E-Banking dipengaruhi oleh variabel persepsi kemudahan teknologi yang dimediasi minat nasabah dan kepercayaan nasabah. Sedangkan sisanya 1,8\% variasi variabel keputusan menggunakan E-Banking dipengaruhi oleh variabel lain yang tidak termasuk dalam penelitian ini.

\section{Uji Asumsi Klasik}

a. Uji Multikolinearitas

Hasil yang diperoleh dalam angka VIF untuk variabel persepsi kemudahan teknologi sebesar 19,040, minat nasabah sebesar 25,166 dan kepercayaan nasabah sebesar 29,158 maka nilai VIF > 10, maka data penelitian digolongkan terdapat gangguan multikolinearitas dalam model regresinya.

b. Uji Heteroskedastisitas

Gambar Scatterplot, menunjukkan titik-titik yang terbentuk menyebar secara acak dan tersebar baik di atas maupun di bawah angka 0 pada sumbu $\mathrm{Y}$, hal ini dapat disimpulkan bahwa tidak terjadi heteroskedastisitas pada model regresi, sehingga model regresi layak dipakai.

c. Uji Autokorelasi

Nilai Durbin-Watson yang diperoleh dalam pengujian ini adalah 1,670 yang dibandingkan dengan nilai tabel DW dengan nilai signifikansi 0,05, jumlah sampel $94(\mathrm{n}=94)$ dan jumlah variabel independen $1(\mathrm{k}=1)$, maka dari tabel DW didapatkan nilai batas bawah (dL) adalah 1,6427 dan nilai batas atas (dU) adalah 1,6857 dan 4-dU = 2,3143. Nilai DW 2,098 sehingga 1,6427<1,670 <2,3143. Hal ini menunjukkan bahwa tidak ada autokorelasi sehingga model regresi layak digunakan.

d. Uji Normalitas

Pada gambar normal probability plot maupun gambar histrogram dapat disimpulkan bahwa gambar histrogram memberikan pola distribusi yang mendekati normal. Sedangkan pada gambar normal probability plot terlihat titiktitik penyebar di sekitar garis diagonal, serta penyebaran mengikuti arah garis diagonal. Kedua grafik ini menunjukkan bahwa modal regresi layak dipakai karena memenuhi asumsi normalitas. 


\section{Pengujian Hipotesis}

1. Pengaruh Persepsi Kemudahan Teknologi terhadap Minat Nasabah

Tabel 4.33.

Analisis Regresi Persepsi Kemudahan Teknologi

Terhadap Minat Nasabah

Coefficients $^{a}$

\begin{tabular}{|c|c|c|c|c|c|c|}
\hline \multirow[b]{2}{*}{ Model } & & \multicolumn{2}{|c|}{$\begin{array}{l}\text { Unstandardized } \\
\text { Coefficients }\end{array}$} & \multirow{2}{*}{$\begin{array}{c}\begin{array}{c}\text { Standardized } \\
\text { Coefficients }\end{array} \\
\text { Beta }\end{array}$} & \multirow[b]{2}{*}{$t$} & \multirow[b]{2}{*}{ Sig. } \\
\hline & & $B$ & Std. Error & & & \\
\hline 1 & (Constant) & -.465 & .349 & & -1.334 & .186 \\
\hline & $\begin{array}{l}\text { Persepsi kemudahan } \\
\text { teknologi }\end{array}$ & 1.054 & .030 & .965 & 35.394 & .000 \\
\hline
\end{tabular}

a. Dependent Variable: Minat nasabah

Sumber : Data primer yang diolah, 2018

Berdasarkan tabel di atas, diketahui angka signifikansi sebesar $0,000<\alpha=$ 0,05 dan $\mathrm{t}$ hitung $=35,394>\mathrm{t}$ tabel $=1,662$, sehingga signifikan maka hipotesis 1 (H1) yang menyatakan persepsi kemudahan teknologi berpengaruh positif terhadap minat nasabah diterima. Arah positif tersebut mengindikasikan bahwa jika persepsi kemudahan teknologi meningkat maka minat nasabah menggunakan juga meningkat.

2. Pengaruh Persepsi Kemudahan Teknologi terhadap Kepercayaan Nasabah

Tabel 4.34.

Analisis Regresi Persepsi Kemudahan Teknologi

Terhadap Kepercayaan Nasabah

\section{Coefficients $^{a}$}

\begin{tabular}{|c|c|c|c|c|c|c|}
\hline \multirow[b]{2}{*}{ Model } & & \multicolumn{2}{|c|}{$\begin{array}{l}\text { Unstandardized } \\
\text { Coefficients }\end{array}$} & \multirow{2}{*}{\begin{tabular}{|c|}
$\begin{array}{c}\text { Standardized } \\
\text { Coefficients }\end{array}$ \\
Beta \\
\end{tabular}} & \multirow[b]{2}{*}{$\mathrm{t}$} & \multirow[b]{2}{*}{ Sig. } \\
\hline & & B & Std. Error & & & \\
\hline 1 & (Constant) & -.548 & .319 & & -1.717 & .089 \\
\hline & $\begin{array}{l}\text { Persepsi kemudahan } \\
\text { teknologi }\end{array}$ & 1.044 & .027 & .970 & 38.289 & .000 \\
\hline
\end{tabular}

a. Dependent Variable: Kepercayaan nasabah

Sumber : Data primer yang diolah, 2018

Berdasarkan tabel 4.34. di atas, diketahui angka signifikansi sebesar $0,000<\alpha=0,05$ dan $\mathrm{t}$ hitung $=38,289>\mathrm{t}$ tabel $=1,662$, sehingga signifikan maka hipotesis $2(\mathrm{H} 2)$ yang menyatakan persepsi kemudahan teknologi berpengaruh positif terhadap minat nasabah diterima. Arah positif tersebut mengindikasikan bahwa jika persepsi kemudahan teknologi meningkat maka kepercayaan nasabah menggunakan juga meningkat. 
Tabel 4.35.

Analisis Regresi Persepsi Kemudahan Teknologi, Minat Nasabah, Kepercayaan NasabahTerhadap Keputusan Menggunakan E-Banking

\begin{tabular}{|c|c|c|c|c|c|}
\hline & icients & & & & \\
\hline \multirow[b]{2}{*}{ Model } & \multicolumn{2}{|c|}{$\begin{array}{c}\text { Unstandardized } \\
\text { Coefficients }\end{array}$} & \multirow{2}{*}{$\begin{array}{c}\begin{array}{c}\text { Standardized } \\
\text { Coefficients }\end{array} \\
\text { Beta }\end{array}$} & \multirow[b]{2}{*}{$\mathrm{T}$} & \multirow[b]{2}{*}{ Sig. } \\
\hline & B & Std. Error & & & \\
\hline (Constant) & -.168 & .180 & & -.931 & .354 \\
\hline $\begin{array}{l}\text { Persepsikemudahantek } \\
\text { nologi }\end{array}$ & -.001 & .066 & -.001 & -.017 & .986 \\
\hline Minatnasabah & .238 & .070 & .237 & 3.424 & .001 \\
\hline Kepercayaannasabah & .775 & .076 & .759 & 10.191 & .000 \\
\hline
\end{tabular}

a. Dependent Variabel :Keputusan Menggunakan E-Banking

Sumber : Data primer yang diolah,2018

3. Pengaruh Persepsi Kemudahan Teknologi terhadap Keputusan Menggunakan EBanking

Berdasarkan tabel 4.35. di atas, diketahui angka signifikansi sebesar 0,986 $>\alpha=0,05$, dan $\mathrm{t}$ hitung $=0,017<\mathrm{t}$ tabel $=1,662$ sehingga tidak signifikan, maka hipotesis 3 (H3) yang menyatakan persepsi kemudahan teknologi berpengaruh positif terhadap keputusan menggunakan E-Banking ditolak. Hal ini mengindikasikan bahwa jika persepsi kemudahan teknologi meningkat atau menurun maka keputusan menggunakan E-Banking tidak berpengaruh. Para nasabah tidak mempermasalahkan kemudahan teknologi E-Banking, dilihat dari sisi responden pada saat ini nasabah sudah memiliki banyak pengetahuan teknologi, mereka beranggapan bahwa persepsi kemudahan teknologi E-Banking yang ada akan belum tentu memberikan solusi masalah transaksi perbankan. Hal ini membuat nasabah merasa kawatir dengan berbagai kemudahan yang diberikan oleh pihak bank, ada sebagian responden yang merasa bahwa kemudahan teknologi yang ditawarkan akan berpengaruh pada data dari pihak nasabah dapat dilihat oleh setiap orang atau transaksi mereka dapat dioperasikan oleh orang lain. Hal inilah yang menyebabkan persepsi kemudahan teknologi tidak berpengaruh terhadap keputusan penggunaan E-Banking, karena suatu teknologi yang ditawarkan belum tentu mudah digunakan. Mereka sudah mengerti tentang teknologi, HP dan komputer. Mudah atau tidaknya teknologi E-Banking, tidak mempengaruhi keputusan nasabah untuk menggunakan layananE-Banking.

4. Pengaruh Minat Nasabah terhadap Keputusan Menggunakan E-Banking

Berdasarkan tabel 4.35. di atas, diketahui angka signifikansi sebesar 0,001 $<\alpha=0,05$ dan $\mathrm{t}$ hitung $=3,424>\mathrm{t}$ tabel $=1,662$, sehingga signifikan maka hipotesis 4 (H4) yang menyatakan minat nasabah berpengaruh positif terhadap keputusan menggunakan E-Banking diterima. Arah positif tersebut mengindikasikan bahwa jika minat nasabah meningkat maka keputusan menggunakan E-Banking juga akan meningkat.

5. Pengaruh Kepercayaan terhadap Keputusan Menggunakan E-Banking

Berdasarkan tabel 4.35. di atas, diketahui angka signifikansi sebesar 0,000 $<\alpha=0,05$ dan $\mathrm{t}$ hitung $=10,191>\mathrm{t}$ tabel $=1,662$ sehingga signifikan, maka 
hipotesis 5 (H5) yang menyatakan kepercayaan nasabah berpengaruh positif terhadap keputusan menggunakan E-Banking diterima. Arah positif tersebut mengindikasikan bahwa jika kepercayaan meningkat maka keputusan menggunakan E-Banking juga akan meningkat.

6. Pengaruh Persepsi Kemudahan Teknologi terhadap Keputusan Menggunakan EBanking Dengan Minat Nasabah Sebagai Variabel Mediasi

Sobel test merupakan uji untuk mengetahui apakah hubungan yang melalui sebuah variabel mediasi secara signifikan mampu sebagai mediator dalam hubungan tersebut. Adapun gambar model mediasinya sebagai berikut :

\section{Gambar 4.10.}

Model Mediasi

Persepsi Kemudahan Teknologi-Minat Nasabah-Keputusan

Menggunakan E-Banking

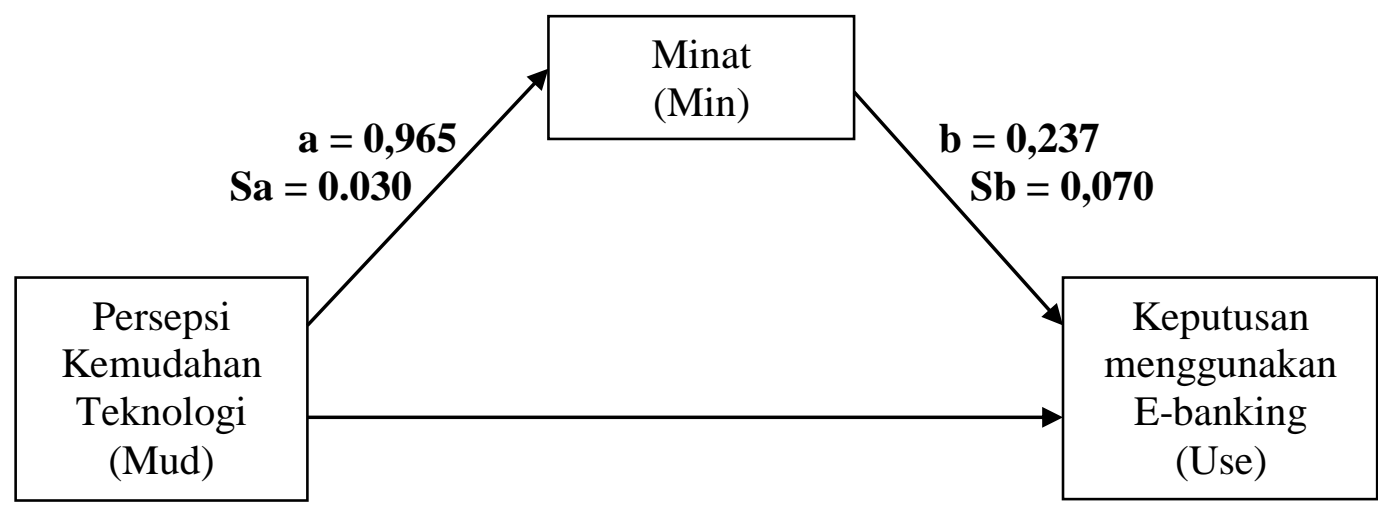

Sumber : dikembangkan pada tesis ini (2018)

Tabel 4.36.

Analisis Regresi Persepsi Kemudahan Teknologi

Terhadap Keputusan Menggunakan E-Banking Dengan Minat Nasabah Sebagai Mediasi

\begin{tabular}{|c|c|c|c|c|}
\hline Input: & & Test statistic: & Std. Error: & p-value: \\
\hline a 0.965 & Sobel test: & 3.36711405 & 0.06792315 & 0.00075959 \\
\hline$b 0.237$ & Aroian test: & 3.36550593 & 0.06795561 & 0.00076403 \\
\hline$s_{a} 0.030$ & Goodman test: & 3.36872448 & 0.06789068 & 0.00075517 \\
\hline$s_{\mathrm{b}} 0.070$ & Reset all & & Calculate & \\
\hline
\end{tabular}

Sumber : Data primer yang diolah, 2018

Berdasarkan tabel 4.36. di atas, diketahui angka signifikansi sebesar 0,000 $<\alpha=0,05$ sehingga signifikandan angka sobel test ( $\mathrm{t}$ hitung) $=3,367>\mathrm{t}$ tabel $=$ 1,662. Dengan demikian maka minat nasabah memediasi pengaruh antara persepsi kemudahan teknologi terhadap keputusan menggunakan E-Banking dengan arah 
positif dan signifikan. Atas dasar informasi tersebut maka hipotesis 6 (H6) diterima. Arah positif dan signifikan tersebut mengindikasikan bahwajika minat nasabah meningkat maka pengaruh persepsi kemudahan teknologi terhadap keputusan menggunakan E-Banking juga akan meningkat.

7. Pengaruh Persepsi Kemudahan Teknologi terhadap Keputusan Menggunakan EBanking Dengan Kepercayaan Sebagai Variabel Mediasi

Gambar 4.11.

Model Mediasi Persepsi Kemudahan Teknologi-Kepercayaan Nasabah-Keputusan Menggunakan E-Banking

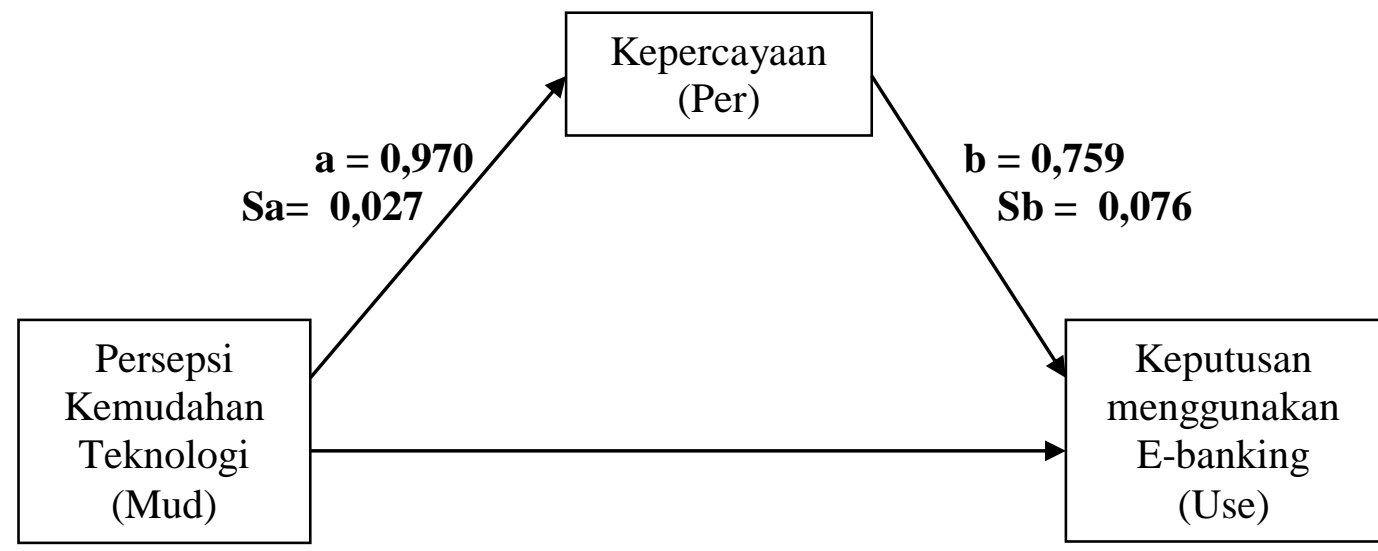

Sumber : dikembangkan pada tesis ini (2018)

Tabel 4.37.

Analisis Regresi Persepsi Kemudahan Teknologi

Terhadap Keputusan Menggunakan E-Banking

Dengan Kepercayaan Nasabah Sebagai Mediasi

\begin{tabular}{|c|c|c|c|c|}
\hline Input: & & Test statistic: & Std. Error: & p-value: \\
\hline a 0.970 & Sobel test: & 9.62198869 & 0.07651537 & 0 \\
\hline b 0.759 & Aroian test: & 9.61853043 & 0.07654288 & 0 \\
\hline$s_{a} 0.027$ & Goodman test: & 9.62545069 & 0.07648785 & 0 \\
\hline$s_{\mathrm{b}} 0.076$ & Reset all & & Calculate & \\
\hline
\end{tabular}

Sumber : Data primer yang diolah, 2018

Berdasarkan tabel 4.37. di atas, diketahui angka signifikansi sebesar 0,000 $<\alpha=0,05$ sehingga signifikandan angka sobel test $(\mathrm{t}$ hitung) $=9,621>\mathrm{t}$ tabel $=$ 1,662. Dengan demikian maka kepercayaan nasabah memediasi pengaruh antara persepsi kemudahan teknologi terhadap keputusan menggunakan E-Banking dengan arah positif dan signifikan. Atas dasar informasi tersebut hipotesis 7 (H7) diterima.Arah positif dan signifikan tersebut mengindikasikan bahwajika 
kepercayaan nasabah meningkat maka pengaruh persepsi kemudahan teknologi terhadap keputusan menggunakan E-Banking juga akan meningkat.

\section{Pembahasan}

1. Pengaruh Persepsi Kemudahan Teknologi terhadap Minat Nasabah

Berdasarkan hasil uji hipotesis (uji t) diketahui bahwapersepsi kemudahan teknologi berpengaruh positif terhadap minat nasabah yang dapat dilihat dari angka signifikansi sebesar $0,000<\alpha=0,05$ dan $\mathrm{t}$ hitung $=35,394>\mathrm{t}$ tabel $=1,661$. Hal ini mengindikasikan bahwa jika persepsi kemudahan teknologi meningkat maka minat nasabah menggunakan juga meningkat.

Persepsi kemudahan teknologi ini dimaksudkan agar nasabah dapat menggunakan layanan E-Banking dengan mudah, baik itu mudah dipelajari, mudah dimengerti, mudah menguasai dan tentunya mudah untuk digunakan. Adanya persepsi kemudahan teknologi, diharapkan nasabah dapat dengan baik dan senang serta menambah minat nasabah dalam melakukan transaksi E-Banking.

Hasil penelitian ini sama dengan penelitian dari Sri (2009) menyatakan bahwa kemudahan berpengaruh positif dan signifikan terhadap minat nasabah menggunakan e-banking. Hasil tersebut didukung oleh penelitian Maria (2017), Mislah (2015) dan Fita (2013).

2. Pengaruh Persepsi Kemudahan Teknologi terhadap Kepercayaan Nasabah

Berdasarkan hasil uji hipotesis (uji t) diketahui bahwapersepsi kemudahan teknologi berpengaruh positif terhadap minat nasabah yang dapat dilihat dari angka signifikansi sebesar $0,000<\alpha=0,05$ dan $\mathrm{t}$ hitung $=38,289>\mathrm{t}$ tabel $=1,661$. Hal ini mengindikasikan bahwa jika persepsi kemudahan teknologi meningkat maka kepercayaan nasabah menggunakan juga meningkat.

Sebagian besar para responden sangat setuju dengan adanya persepsi kemudahan teknologi serta menganggap persepsi kemudahan teknologi dapat meningkatkan kepercayaan nasabah dalam bertransaksi menggunakan E-Banking dan nasabah merasa nyaman dalam melakukan transaksi. Semakin tinggi persepsi kemudahan teknologi yang diberikan semakin tinggi pula kepercayaan nasabah untuk menggunakan layanan E-Banking.

Hasil penelitian ini sama dengan penelitian dari Fita (2013) yang menyatakan bahwa kemudahaan penggunaan berpengaruh positif terhadap kepercayaan nasabah dalam menggunakan internet banking.

3. Pengaruh Persepsi Kemudahan Teknologi terhadap Keputusan Menggunakan EBanking

Berdasarkan hasil uji hipotesis (uji t) diketahui bahwapersepsi kemudahan teknologi tidak berpengaruh terhadap keputusan menggunakan E-Banking yang dapat dilihat dari angka signifikansi sebesar $0,986>\alpha=0,05$, dan $t$ hitung $=0,017<$ $\mathrm{t}$ tabel $=1,661$. Hal ini mengindikasikan bahwa jika persepsi kemudahan teknologi meningkat atau menurun maka minat nasabah dalam menggunakan E-Banking tidak berpengaruh.

Para nasabah tidak mempermasalahkan kemudahan teknologi E-Banking, karena pada saat ini nasabah sudah memiliki banyak pengetahuan. Mereka sudah mengerti tentang teknologi, HP dan komputer. Pada saat ini responden telah banyak memiliki pengetahuan tentang teknologi, mereka beranggapan bahwa persepsi kemudahan teknologi E-Banking yang ada akan belum tentu memberikan solusi masalah transaksi perbankan. Ada sebagian responden yang masih merasa kawatir 
mengenai kemudahan teknologi yang diberikan oleh pihak bank. Ada juga sebagian responden yang merasa bahwa kemudahan teknologi yang ditawarkan akan berpengaruh pada data dari pihak nasabah dapat di lihat oleh setiap orang atau transaksi mereka dapat dioperasikan oleh orang lain. Hal inilah yang menimbulkan bahwa persepsi kemudahan teknologi tidak berpengaruh terhadap keputusan menggunakan E-Banking.

Hasil penelitian ini berbeda dengan penelitian dari Firda (2017) yang menyatakan bahwa kemudahan penggunaan berpengaruh positif terhadap adopsi internet banking BNI.

4. Pengaruh Minat Nasabah terhadap Keputusan Menggunakan E-Banking

Berdasarkan hasil uji hipotesis (uji t) diketahui bahwaminat nasabah berpengaruh positif terhadap keputusan menggunakanE-Banking yang dapat dilihat dari angka signifikansi sebesar $0,001<\alpha=0,05$ dan $\mathrm{t}$ hitung $=3,424>\mathrm{t}$ tabel $=$ 1,661. Hal ini mengindikasikan bahwa jika minat nasabah meningkat maka keputusan menggunakan E-Banking juga akan meningkat.

Minat nasabah merupakan tahap kecenderungan nasabah untuk bertindak sebelum keputusan benar-benar dilaksanakan. Semakin meningkat minat nasabah dalam melakukan pencarian informasi, ketertarikan dan kesediaan dalam layanan E-Banking dapat meningkatkan keputusan menggunakan layanan E-Banking.

Hasil penelitian ini sama dengan penelitian dari Sri (2009) menyatakan bahwa minat nasabah berpengaruh positif dan signifikan terhadap keputusan dalam bertransaksi dengan E-Banking.

5. Pengaruh Kepercayaan terhadap Keputusan Menggunakan E-Banking

Berdasarkan hasil uji hipotesis (uji t) diketahui bahwa kepercayaan nasabah berpengaruh positif terhadap keputusan menggunakan E-Banking yang dapat dilihat dari angka signifikansi sebesar $0,000<\alpha=0,05$ dan $\mathrm{t}$ hitung $=10,191>\mathrm{t}$ tabel $=$ 1,661. Hal ini mengindikasikan bahwa jika kepercayaan meningkat maka keputusan menggunakan E-Banking juga akan meningkat.

Upaya dalam mempertahankan hubungan jangka panjang dengan para nasabah, pihak bank memerlukan suatu konsep kepercayaan pelanggan terhadap akselerasi jasa elektronik agar bank dapat mempertahankan eksistensinya dalam era E-Banking. Seiring dengan maraknya kejahatan elektronik seperti pembobolan akun, faktor kepercayaan menjadi hal yang sangat penting dalam penggunaan $E$ Banking dalam transaksi perbankan. Oleh karena itu, tingkat kepercayaan nasabah terhadap perbankan sangat menentukan keputusan nasabah tersebut dalam menggunakan layanan E-Banking.

Hasil penelitian ini sama dengan penelitian dari Firda (2017) yang menyatakan bahwa kepercayaan berpengaruh terhadap sikap dalam penggunaan mobile banking.

6. Pengaruh Persepsi Kemudahan Teknologi terhadap Keputusan Menggunakan EBanking Dengan Minat Nasabah Sebagai Variabel Mediasi

Berdasarkan hasil uji hipotesis (uji t) diketahui bahwa minat nasabah memediasi pengaruh antara persepsi kemudahan teknologi terhadap keputusan menggunakan E-Banking yang dapat dilihat dari angka signifikansi sebesar 0,000 $<\alpha=0,05$ dan angka sobel test ( $\mathrm{t}$ hitung) $=3,367>\mathrm{t}$ tabel $=1,661$. Hal ini mengindikasikan bahwa jika minat nasabah meningkat maka pengaruh persepsi kemudahan teknologi terhadap keputusan menggunakan E-Banking juga akan meningkat. 
Persepsi kemudahan teknologi merupakan perspektif memberikan indikasi bahwa suatu teknologi dirancang bukan untuk menyulitkan pemakainya, akan tetapi penggunaan teknologi justru mempermudah seseorang dalam menyelesaikan pekerjaannya. Sehingga apabila nasabah merasakan kemudahan dalam mengoperasikan layanan E-Banking maka dapat meningkatkan minat nasabah untuk mengambil keputusan dalam menggunakan layanan tersebut.

Hasil penelitian ini sama dengan penelitian dari Sri (2009) menyatakan bahwa kemudahan berpengaruh positif dan signifikan terhadap minat nasabah menggunakan e-banking. Hasil tersebut didukung oleh penelitian Maria (2017),Mislah (2015) dan Fita (2013). Penelitian yang dilakukan oleh Sri (2009) menyatakan bahwa minat nasabah dapat memediasi hubungan antara perceived easy of use (kemudahan)dengan keputusan dalam bertransaksi dengan internet banking.

7. Pengaruh Persepsi Kemudahan Teknologi terhadap Keputusan Menggunakan EBanking Dengan Kepercayaan Sebagai Variabel Mediasi

Berdasarkan hasil uji hipotesis (uji t) diketahui bahwakepercayaan nasabah memediasi pengaruh antara persepsi kemudahan teknologi terhadap keputusan menggunakan E-Banking yang dapat dilihat dari angka signifikansi sebesar 0,000 $<\alpha=0,05$ dan angka sobel test ( $\mathrm{t}$ hitung) $=9,621>\mathrm{t}$ tabel $=1,661$. Hal ini mengindikasikan bahwajika kepercayaan nasabah meningkat maka pengaruh persepsi kemudahan teknologi terhadap keputusan menggunakan E-Banking juga akan meningkat.

Persepsi kemudahan teknologi mempunyai makna tanpa adanya kesulitan atau tidak perlu berusaha keras. Dengan demikian, persepsi kemudahan teknologi ini merujuk pada kepercayaan individu bahwa setiap sistem ini membantu dan tidak memerlukan upaya serta biaya yang besar dalam penggunaannya.

Hasil penelitian ini sama dengan penelitian dari Fita (2013) yang menyatakan bahwa kemudahaan penggunaan berpengaruh positif terhadap kepercayaan nasabah dalam menggunakan internet banking. Penelitian yang dilakukan oleh Firda (2017) yang menyatakan bahwa kepercayaan berpengaruh terhadap sikap dalam penggunaan mobile banking.

\section{SIMPULAN}

Berdasarkan hasil penelitian dan pembahasan di atas, maka dapat disimpulkan bahwa Persepsi kemudahan teknologi berpengaruh positif terhadap minat nasabah yang dapat dilihat dari angka signifikansi sebesar $0,000<\alpha=0,05$ dan angka $t$ test $=35,394>t$ tabel $=1,661$ sehingga hipotesis $(\mathrm{H} 1)$ yang menyatakan bahwa persepsi kemudahan teknologi berpengaruh positif terhadap minat nasabah diterima. Persepsi kemudahan teknologi berpengaruh positif terhadap kepercayaan nasabah yang dapat dilihat dari angka signifikansi sebesar $0,000<\alpha=0,05$ dan angka $t$ test $=38,289>\mathrm{t}$ tabel $=1,661$ sehingga hipotesis (H2) yang menyatakan bahwa persepsi kemudahan teknologi berpengaruh positif terhadap kepercayaan nasabah diterima. Persepsi kemudahan teknologi tidak berpengaruhterhadap keputusan menggunakan E-Banking yang dapat dilihat dari angka signifikansi sebesar $0,986>\alpha=0,05$ dan angka $t$ test $=0,017<\mathrm{t}$ tabel $=1,661$ sehingga hipotesis $(\mathrm{H} 3)$ yang menyatakan bahwa persepsi kemudahan teknologi berpengaruh positif terhadap keputusan menggunakan E-Banking ditolak. Minat 
nasabah berpengaruh positif terhadap keputusan menggunakan E-Banking yang dapat dilihat dari angka signifikansi sebesar $0,001<\alpha=0,05$ dan angka $\mathrm{t}$ test $=3,424>\mathrm{t}$ tabel $=$ 1,661 sehingga hipotesis (H4) yang menyatakan bahwa minat nasabah berpengaruh positif terhadap keputusan menggunakan E-Banking diterima. Kepercayaan nasabah berpengaruh positif terhadap keputusan menggunakan E-Banking yang dapat dilihat dari angka signifikansi sebesar $0,000<\alpha=0,05$ dan angka $t$ test $=10,191>\mathrm{t}$ tabel $=1,661$ sehingga hipotesis (H5) yang menyatakan bahwa kepercayaan nasabah berpengaruh positif terhadap keputusan menggunakan E-Banking diterima. Persepsi kemudahan teknologi berpengaruh positif terhadap keputusan menggunakan E-Banking dengan minat nasabah sebagai mediasi yang dapat dilihat dari angka signifikansi sebesar $0,000<\alpha=0,05$ dan angka $\mathrm{t}$ test $=3,367>\mathrm{t}$ tabel $=1,661$ sehingga hipotesis $(\mathrm{H} 6)$ yang menyatakan bahwa persepsi kemudahan teknologi berpengaruh positif terhadap keputusan menggunakan E-Banking dengan minat nasabah sebagai mediasi diterima. Persepsi kemudahan teknologi berpengaruh positif terhadap keputusan menggunakan $E$ Banking dengan kepercayaan nasabah sebagai mediasi yang dapat dilihat dari angka signifikansi sebesar $0,000<\alpha=0,05$ dan angka t test $=9,621>\mathrm{t}$ tabel $=1,661$ sehingga hipotesis (H7) yang menyatakan bahwa persepsi kemudahan teknologi berpengaruh positif terhadap keputusan menggunakan E-Banking dengan kepercayaan nasabah sebagai mediasi diterima.

\section{DAFTARPUSTAKA}

Andanawari. 2013. Hubungan Antara Tipe Kepribadian dengan Posttraumatic Growth pada Orang dengan HIV/AIDS. Jurnal Universitas Pendidikan Indonesia.

Davis, F.D., 2011, Perceived Usefulness, Perceived Ease of Use, and User Acceptance of Information Technology. MS Quarterly (online), Vol. 13.

Firda Rohmah Amelia. 2017. Pengaruh Kemudahan, Manfaat, Keamanan, Kenyamanan, Dan Kepercayaan Nasabah Terhadap Adopsi Internet Banking Pada Bank BNI di Surabaya. Jurnal STIE Perbanas Surabaya. Vol. II No. 1 Halaman 1-19.

Fita Pertiwi. 2013. Pengaruh Risiko, Manfaat Dan Kemudahan Penggunaan Terhadap Kepercayaan Nasabah Dalam Menggunakan Internet Banking Di Yogyakarta (Studi Kasus Pada Nasabah Bank Mandiri). Jurnal Universitas PGRI. Yogyakarta. Vol. 1 No. 1 Halaman 421-434.

Ghozali, Imam. 2011. Aplikasi Analisis Multivariate Dengan Program SPSS IBM SPSS 23. Penerbit Universitas Diponegoro. Semarang.

Gujarati, Damodar. 2013. Dasar-dasar Ekonometrika. Salemba Empat. Jakarta.

Husein Umar. 2011. Metode Penelitian untuk Skripsi dan Tesis Bisnis. Rajawali Pers. Jakarta.

Jogiyanto. 2007. Sistem Teknologi Keperilakuan. Penerbit Andi. Yogyakarta.

Jonathan Sarwono. 2007. Analisis Jalur untuk Riset Bisnis dengan SPSS. Penerbit Andi. Yogyakarta. 
Kasmir. 2014. Pemasaran Bank. Kencana. Jakarta.

Kotler, Philip dan Gary Amstrong. 2010. Prinsip-Prinsip Pemasaran. Erlangga. Jakarta.

Kotler, Philip dan Keller, Kevin Lane. 2009. Manajemen Pemasaran. Erlangga. Jakarta.

Kusmayadi. 2017. Pengaruh Relationship Quality Terhadap Loyalitas Nasabah Tabungan, STIE STAN Indonesia Mandiri.

Maria Batista. 2017. Analisis Faktor-Faktor Yang Mempengaruhi Minat Nasabah Menggunakan Internet Banking (Studi Kasus Nasabah Bank BCA Di Kota Palembang). Jurnal Akuntansi STIE Multi Data Palembang. Vol. 1 No. 1 Halaman 1-17.

Maryanto Supriyono. 2010. Buku Pintar Perbankan. Penerbit Andi. Yogyakarta.

Masri Singarimbun dan Sofyan Effendi. 2013. Metodologi Penelitian Survei. Liberty. Jakarta.

Mislah Hayati Nasution. 2015. Faktor-Faktor Yang Mempengaruhi Minat Nasabah Terhadap Internet Banking. Jurnal Nisbah Vol. 1 No. 1 Tahun 2015 Halaman 62-73.

Nuary. 2010. Implementasi Theory of Planned Behavior dalam Adopsi E-Commerce oleh UKM. Jurnal Manajemen Bisnis.

Poon, W. C. 2010. Users' Adoption of e-banking Services. Journal of Business \& Industrial Marketing. Vol.23, No.1, hal.59-69. the Malaysian perspectivell.

Schiffman, Leon dan Kanuk, Leslie Lazar. 2008. Perilaku Konsumen. Indeks. Jakarta.

Setyobudi. 2008. Aplikasi Theory of Planned Behavior (TPB) terhadap Perilaku Berbagi Pengetahuan (Knowledge Sharing) dalam Organisasi. National Conference on Management Research. ISBN.

Sri Ismulyaty. 2009. Pengaruh Trust, Risk Dan Technology Acceptance Models Terhadap Keputusan Nasabah Dengan Minat Nasabah Sebagai Variabel Intervening. Jurnal Ekombis Review, Vol. 2 No. 1 Halaman 1-7.

Sugiyono. 2010. Metode Penelitian Bisnis. Alfabeta. Bandung.

Syamsul Hadi. 2014. Faktor-Faktor Yang Mempengaruhi Penggunaan Layanan Mobile Banking. Jurnal Universitas Islam Indonesia, Vol. 1 No. 1 Halaman 55-67.

Widya Atika Safitri. 2016. Pengaruh Persepsi Resiko, Kemudahan, Kegunaan, dan Kepercayaan Terhadap Sikap Dalam Penggunaan Mobile Banking (Survey Pada Nasabah Bank BRI, Bank Mandiri dan Bank BNI di Solo). Jurnal Universitas Muhammadiyah Surakarta. Vol. 2 No. 2 Halaman 1-15. 
Widyarini. 2005. Analisis Niat Perilaku Menggunakan Internet Banking di Kalangan Pengguna Internet di Surabaya. Jurnal Manajemen \& Akuntansi, Vol 5 No. 1 April 2005.

www.tekno.kompas.com. diakses pada tanggal 16 Agustus 2018 pukul 15:10 WIB. http://apjii.or.id.survei

www.kontan.co.id. diakses pada tanggal 16 Agustus 2018 pukul 16:02 WIB. http://kontan.co.id 